\title{
酸・アルカリ処理による野菜類及び いも類の組織崩壊
}

\author{
釘 宮 正 往* \\ Disintegration of Edible Tissues of Vegetables and Potatoes by \\ Successive Treatments with Acid and Alkali \\ Masayuki KugImIYA* \\ * Department of Food and Nutrition, Hiroshima Women's University, \\ 1-1-71, Ujina-higashi, Minami-ku, Hiroshima 734
}

\begin{abstract}
The successive treatments with acid and alkali or the single treatment with alkali were applied to disintegrate the edible tissues of vegetables and potatoes as follows. The samples were immersed in hydrochloric acid at $35^{\circ} \mathrm{C}$ for 1 or 24 hours, where the $\mathrm{pH}$ values of the supernatant were $1.0 \sim 1.5$. The samples treated with acid were stirred in a sodium hydroxide solution by a magnetic stirrer at room temperature for 2 hours, where the $\mathrm{pH}$ values of the supernatant were 12.5 13.0. The degree of disintegration was calculated on the basis of the weights of the tissues used and those remained after the treatments. It was found that the single treatment with alkali disintegrated almost completely the tissues of tomato, squash and sweet potato. The successive treatments with acid and alkali disintegrated almost completely the tissues of cucumber, eggplant, sweet pepper, onion, garlic, lily root, taro, and potato. The successive treatments disintegrated $50 \sim 100 \%$ of the tissues of cabbage, chinese cabbage, lettuce, spinach, green asparagus and broccoli. The large scatter of the disintegration degree was assumed to be due to the heterogeneity of the tissues and fibrous tissues which may be difficult to be disintegrated by the treatments. The tissues of Japanese radish, carrot, burdock, lotus root, ginger and arrowhead, were found to be difficult to be disintegrated by the successive treatment, in which the degree of disintegration was less than $28 \%$. From these results it was assumed that the relative difficulty of disintegration of tissues by the treatments may reflect a difference in the mechanism of adhesion or the strength of adhesion of tissues.

(Received Jun. 10, 1993)
\end{abstract}

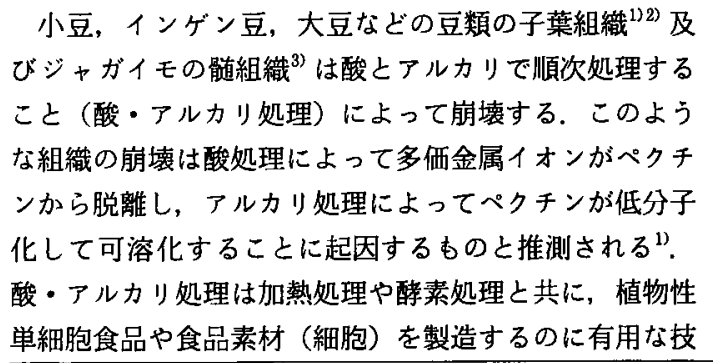

*広島女子大学（勇734 広島市南区宇品東 1-1-71）
術となる可能性を秘めている．一方，酸・アルカリ処理 による組織の崩壊の難易は組織の接着機構の違いを反映 するのではないかと考えられる。

今回は，酸・アルカリ処理の有効性を知る目的で，ま た組織の接着機構についての知見を得る目的で，野菜類 及びいる類に酸・アルカリ処理を適用して得られた結果 について報告する. 


\section{実 験 方 法}

\section{1. 試 料}

野菜類は葉菜類としてキャベッ，ハクサイ，レタス， ホウレンソウ, 茎菜類としてタマネギ, ニンニク, ユリ 根，グリーンアスパラガス，根菜類として夏ダイコン， 冬ダイコン, ニンジン, ゴボウ, レンコン, クワイ, シ ョウガ, 果菜類としてカボチャ, キュウリ，トマト，ナ ス,ピーマン, 花菜類としてプロッコリーを用いた、い も類はサッマイモ, サトイモ，ジャガイモを用いた，い ずれも市販品で食べ頃のものを皮, 芯, 種子を除いて， $5 \mathrm{~mm}$ 角に切って用いた. なお，グリーンアスパラガ スは先端から約 $7 \mathrm{~cm}$ までを, ブロッコリーは花の部分 を用いた. タマネギ, ニンニクは牙を除いて，またカボ チャは種子の周辺部の柔らかい部分を除いて用いた。

\section{2. 酸・アルカリ処理方法}

酸・アルカリ処理による組織崩壊及び崩壊度の測定は 特別に断らない限り前報 ${ }^{2}$ の方法に従って行った，酸処 理では試料 $1 \pm 0.01 \mathrm{~g}$ に塩酸 $10 \mathrm{ml}$ を加えて $35^{\circ} \mathrm{C}$ で 1 時間浸漬した。アルカリ処理では水酸化ナトリウム溶液 $10 \mathrm{~m} l$ を加えて室温で 2 時間擋拌した. この条件で組織 が十分に崩壊しない場合には酸浸漬を 24 時間行った。 崩壊度（\%）は用いた試料の重量とアルカリ処理後の未 崩壊物の重量から求めた。なお，崩壊度に及ぼす酸処理 $\mathrm{pH}$ の影響を調べる場合にはアルカリ処理条件を固定し (0.1M 水酸化ナトリウム溶液使用), アルカリ処理 $\mathrm{pH}$ の影響を調べる場合には酸処理条件を固定した（検討結 果に基づいて適正な濃度の塩酸を使用した)，組織崩壊 に酸処理が不要の場合，アルカリ処理のみを行った．末 崩壊組織を収集するのが難しい場合，ガーゼを用いて収 集した．組織が崩壊した場合には崩壊の状態を顕微鏡で 観察した.

\section{3. 試料の硬さの判定方法}

酸・アルカリ処理後の試料の硬さを酸とアルカリの代 わりに蒸留水を用いて浸清，擋找した試料を対照として， 親指と中指で軽く押さえて感覚的に判定した。

\section{実 験 結 果}

\section{1.トマトの組織崩壊に及ぼすアルカリ処理の影霎}

トマトの組織崩壊に酸処理は不要であったので, アル カリ処理のみを行って崩填度に及ぼすアルカリ処理時の $\mathrm{pH}$ の影響を調べた（Fig. 1)。その結果，アルカリの 代わりに水を加えて擋抖するだけでも崩壊度は約 $70 \%$ であったが， アルカリ処理を行うと $\mathrm{pH}$ が高くなるの

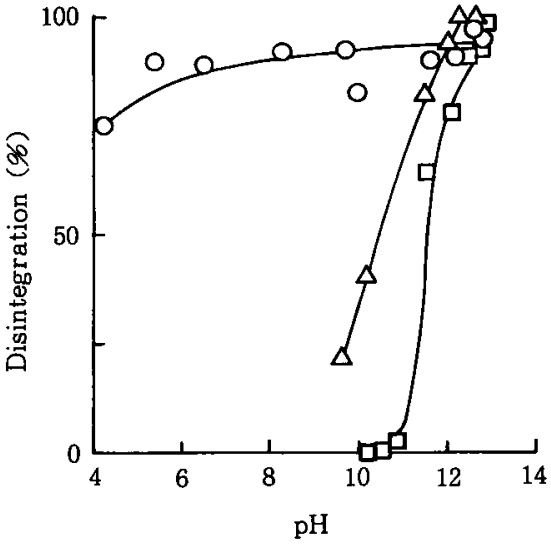

Fig. 1 Effect of $\mathrm{pH}$ of immersing solution on disintegration of tissues in alkali treatment

The treatment with alkali was carried out without pretreatment with acid.

$\bigcirc$ : tomato, $\triangle$ : squash, $\square$ : sweet potato

に伴って崩壊度はやや増加し, $\mathrm{pH}$ が約 12.0（0.04 M 水酸化ナトリゥム使用, 以下同じ）で約 $90 \%$ であった. 崩壊したものを顕微鏡で観察したところ，分離した細胞 が認められた。

2. カボチャ, サッマイモの組織崩壊に及ぼすアルカ リ処理の影震

カボチャあ組織崩壊に酸処理は不要であったので，丁 ルカリ処理のみの影響を調べた（Fig. 1). その結果, $\mathrm{pH}$ が高くなるのに伴って崩壊度は著しく堌加し, $\mathrm{pH}$ が約 $12.5(0.04 \mathrm{M}$ 水酸化ナトリウム) でほぼ $100 \%$ に なることがわかった. トマトの場合と異なってカボチャ の組織崩壊には必ずアルカリ処理が必要であった．崩壊 したものを顕微鏡で観察したところ，多数のデンプン粒 を含む細胞が認められた。

サッマイモの場合にも組織崩壊に酸処理は不要で，ア ルカリ処理のみで組織が崩壊した（Fig. 1)，組織がほ ぼ完全に崩壊するには $\mathrm{pH}$ を約 13.0 (0.1 M 水酸化ナ トリウム）にする必要があった．崩壊したすのを顕微鏡 で観察したところ，大部分の細胞は壊れており，細胞の 外にデンプン粒が認められた。

3. キュウリ，ジャガイモの組織崩壊に及ぼす酸・ア ルカリ処理の影需

キュウリの組織崩壊に及ぼす酸・アルカリ処理の影響 を調べた（Fig. 2). 酸処理の $\mathrm{pH}$ の影響はアルカリ処 


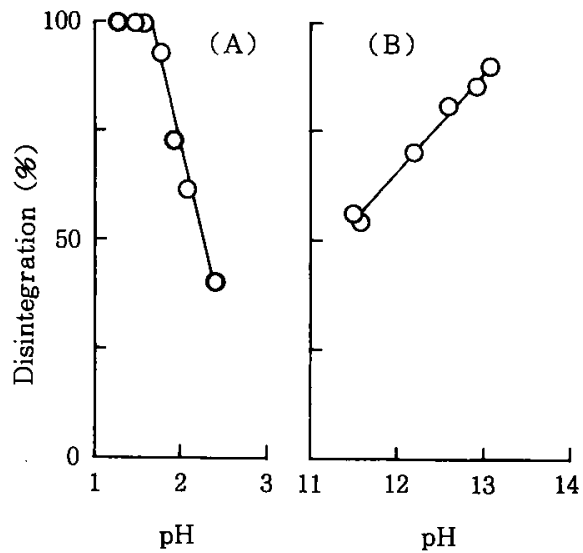

Fig. 2 Effect of $\mathrm{pH}$ of immersing solution for pretreatment with acid (A) and treatment with alkali (B) on disintegration of tissues of cucumber

(A) The alkali treatment after the acid treatment was carried out at $\mathrm{pH}$ approximate 13.3. (B) The acid treatment before the alkali treatment was carried out at $\mathrm{pH}$ approximate 1.6.

理時の $\mathrm{pH}$ を 13.3 に固定し，アルカリ処理 $\mathrm{pH}$ の影響 は酸処理時の $\mathrm{pH}$ を約 1.6 に固定してそれぞれ調べた. その結果, 酸処理では $\mathrm{pH}$ が低くなるのに伴って崩壊 度は增加し， pH 約 $1.6(0.06 \mathrm{M}$ 塩酸) でほぼ $100 \%$ に達した。アルカリ処理では $\mathrm{pH}$ が高くなるのに伴っ て増加し, $\mathrm{pH}$ 約 13.0 (0.08 M 水酸化ナトリウム)で ほぼ約 $90 \%$ になった。これらの結果から,酸・アルカ リ処理はキュウリの組織をほぼ完全に崩壊することが分 かった，崩壊したあのを顕微鏡で観察したところ，分離 した細胞が認められた。

ジャガイモもキュウリと同様に酸・アルカリ処理によ って組織が崩壊した，図示していないが，ほぼ完全に崩 壊するための条件は酸処理が $\mathrm{pH}$ 約 1.0 (0.2 M 塩酸), アルカリ処理が $\mathrm{pH}$ 約 $13.0(0.06 \mathrm{M}$ 水酸化ナトリウ ム）であった。この結果は酸・アルカリによってジャガ イモの細胞を分離した佐藤ら ${ }^{3)}$ の結果とほぼ同じであっ た. なお，顕微鏡観察で細胞と共に壊れた細胞も認めら れた.

キュウリやジャガイモと同様に酸・アルカリ処理によ って組織がはぼ完全に崩壊した野菜類，いも類はナス， ピーマン, タマネギ, ニンニク, エリ根, サトイモであ った。これらの野菜類，いあ類の酸，アルカリ処理時の
およその $\mathrm{pH}$ と崩壊度は，図示していないがそそれぞ れナスは $1.5(0.08 \mathrm{M}$ 塩酸), $13.0(0.1 \mathrm{M}$ 水酸化ナト リゥム)で90 100\%，ピーマンは 1.5 (0.08 M 塩酸), 13.0 (0.08 M 水酸化ナトリウム) で 95 100\%, 夕マ ネギは $1.4(0.1 \mathrm{M}$ 塩酸), $13.0(0.08 \mathrm{M}$ 水酸化ナトリ ウム) で 95\%, ニンニクは $2.3(0.03 \mathrm{M}$ 塩酸, 24 時間 処理), 12.0 (0.02 M 水酸化ナトリウム)で $100 \%$, ユリ根は $1.0(0.2 \mathrm{M}$ 塩酸), $13.0(0.06 \mathrm{M}$ 水酸化ナト リウム)で $90 \%$ ，サトイモは 1.0 (0.2M 塩酸)， 13.0 (0.1M 水酸化ナトリウム)で $90 \%$ であった，顕微鏡 観察の結果, いずれの場合む分離した細胞が認められた。

4. ハクサイの組織崩塄に及ぼす酸・アルカリ処理の 影夦

八クサイの組織崩壊に及ぼす酸・アルカリ処理の影響 を調べた。酸処理を 1 時間行ったところ崩壊度が低かっ たので 24 時間行うこととした. その結果, Fig. 3 に示 したように，酸処理では $\mathrm{pH}$ が低いほど，アルカリ処 理では $\mathrm{pH}$ が高いほど組織が崩壊しやすくなることが 分かった。 ハクサイの組織の崩壊は酸処理 $\mathrm{pH} 1.06 .2$
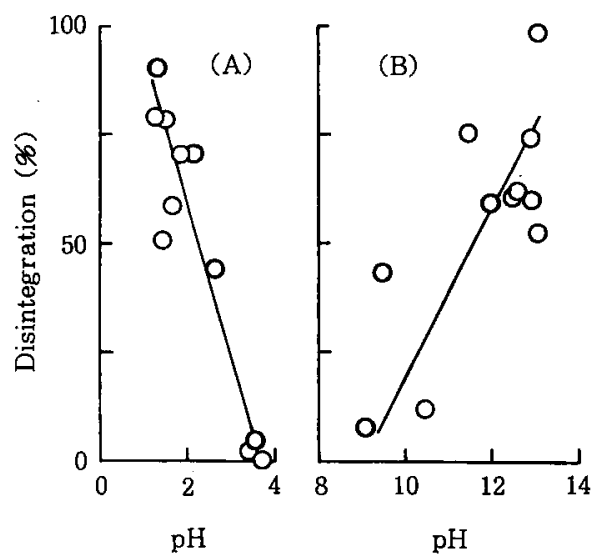

Fig. 3 Effect of $\mathrm{pH}$ of immersing solution for pretreatment with acid (A) and treatment with alkali (B) on disintegration of tissues of chinese cabbage

The sample was immersed in hydrochloric acid at $35^{\circ} \mathrm{C}$ for 24 hours. (A) The alkali treatment after the acid treatment was carried out at $\mathrm{pH}$ approximate 13.2. (B) The acid treatment before the alkali treatment was carried out at $\mathrm{pH}$ approximate 1.0 . 
$\mathrm{M}$ 塩酸), アルカリ処理 $\mathrm{pH} 13.0$ (0.06 M 水酸化ナト リウム）で崩壊度が 55〜95\% とばらつきが大きかった ・崩壞度のばらつきが大きかったことはキュウリの場合 と異なっていた．顕微鏡観察で分離した細胞と共に数個 の細胞が接着したものが多数認められた.

ハクサイと同じようにばらつきの大きい崩買度を示し た野菜はキャベッ，レタス，ホゥレンソウ，グリーンア スパラガス, ブロッコリーであった．これらの野菜類の 酸, アルカリ処理時のおよその $\mathrm{pH}$ と崩壊度は, 四示 していないが，それぞれキャベッは1.0(0.2 M 塩酸)， $13.0(0.06 \mathrm{M}$ 水酸化ナトリウム)で $50 \sim 100 \%$, レタス は $1.0(0.2 \mathrm{M}$ 塩酸, 24 時間処理)，13.5(0.1 M水酸 化ナトリゥム) で 70〜90\%，ホゥレンソウは $1.5(0.08$ $\mathrm{M}$ 塩酸)，13.5(0.1 M 水酸化ナトリウム) で 60〜100 $\%$ ，グリーンアスパラガスは1.0(0.2 M 塩酸)， 13.5 (0.1 M 水酸化ナトリウム) で50９0\%，ブロッコリー は 1.0 (0.2 M 塩酸, 24 時間処理), 13.0 (0.08M 水酸 化ナトリウム) で50〜100\%であった，従って，これら の野菜の崩壊は八クサイの場合と同様に崩壊度が 50 〜 100\%とばらつきが大きいことが分かった，崩壊したも のを顕微鏡観察したところ，いずれの場合す分離した細 胞と共に数個の細胞が接着したものが多数認められた。 このことは同一組織内での接着機構の不均一性を示唆し ているのではないかと考えられる，また，崩壊度のばら つきはこれらの野菜に含まれる葉脈などの瀻維状組織が 酸・アルカリ処理によって崩壊しにくいことに起因する のではないかと考えられる。

5. ダイコン, ニンジン, ゴボウ, レンコン, クワイ, ショウガの組織崩壊及び軟化に及ぼす酸・アルカ リ処理の影響

ダイコン, ニンジン, ゴボウ, レンコン, クワイ, シ ヨウガは酸・アルカリ処理で組織が崩壊しにくいことが 分かったので, 酸処理で $0.2 \mathrm{M}$ 塩酸で 24 時間浸漬し, アルカリ処理で $0.1 \mathrm{M}$ 水酸化ナトリウム溶液を用いて 検討した。 その結果, 酸処理 $\mathrm{pH}$ 約 1.0 ，アルカリ処理 $\mathrm{pH}$ 約 13.3 の条件下で組織の崩壊度（\%) は夏ダイコ ン $24 \sim 28$, 冬ダィコン $0 \sim 5$, ニンジン 10 , ゴボゥ 16〜 20, レンコン2〜 7, クワイ 5〜11, ショウガ 4〜10であ った.これらの結果から,ダイコン, ゴボウ, レンコン, クワイ、ショウガは酸・アルカリ処理による崩壊度が $28 \%$ 以下であり，組織が崩壊しにくいことが分かった.

これらの野菜類を加熱調理した場合，比較的軟化しゃ すいもの之軟化しにくいものがあり，レンコン，ゴボウ は, ダイコン, ニンジンに比べて軟化しにくい(4) 6). そ
こで，酸・アルカリ処理後の硬さを調べたところ，対照 に比べて冬ダイコン：ンジン，クワイは軟らかくなっ たが, ゴボウ,レンコン, ショウガは軟らかくならなか った.この結果から, 酸・アルカリ処理によって組織が 崩壊しにくい野菜類の中に，処理によって軟化するもの としないあのがあることが分かった。

\section{考 察}

以上の結果に基づいて, 組織崩壊の難易と植物の器 官 $^{73)}$ との関係をみると, 果菜類のカボチャ, トマト, いも類のサッマイモはアルカリ処理のみで組織がほぼ完 全に崩壊した，果菜類のキュウリ，ナス，ピーマン，茎 菜類のタマネギ, ニンニク, ュリ根, い屯類のサトイモ, ジャガイモは酸・アルカリ処理によってほぼ完全に組織 が崩壊した．茥菜類のグリーンアスパラガス，花菜類の ブロッコリー，葉菜類のキャベッ，八クサイ，レタス， ホウレンソウは崩壊度にばらつきはあるあのの, 酸・ア ルカリ処理によって組織の $50 \%$ 以上が崩壊した。根菜 類のダイコン，ニンジン，ゴボウ，レンコン，クワイ, ショウガは酸・アルカリ処理によって組織が崩壊しにく かった。これらの結果から，野菜類の器官による組織崩 壊の難易は根菜類が最も崩壊しにくく,おおよそ葉菜類, 茎菜類, 果菜類の順で崩壊しやすくなり，いあ類は果菜 類, 茎菜類と同程度に崩壊しやすいことが分かった。こ のような酸・アルカリ処理による組織の崩壊の難易は器 官, 組織の接着機構の違いや接着力の違いを反映してい るのではないかと考えられる.

酸・アルカリ処理による組織崩壊における酸, アルカ リの作用として，酸はペクチン同士を結び付けている多 価金属イオンを離すことによって，またペクチンを部分 的に加水分解することによって，一部のペクチンの可溶 化を促進し，アルカリは $\beta$ 脱離反応によってペクチン を低分子化しペクチンの可溶化を一層促進することでは ないかと考えられる1!

一方，加熱調理した野菜類の軟化の難易がペクチンの 質や量と関係が深いことが報告されている 結果を報告されている加熱による軟化度（文献 5 の Table 1）と比較すると,アルカリ単独処理または酸 ・アルカリ処理によって組織が崩壊しやすいものはおお む如加熱による軟化度が高い，酸・アルカリ処理によっ て組織が崩壊しにくかったすののうち，ダイコン、ニン ジンは軟化度が高いが、レンコン、ゴボウは低い、ゴボウ とダイコンの蕉熟軟化性の違いは細胞の大きさと形, 細 胞壁構成成分の含量などの相違によるのではないかと報 
告されている6). 従って，酸・アルカリ処理による組織 崩壊の難易は，根菜類で例外はあるものの，加熱調理に よる軟化性と類似していると考えられる。

本研究で得られた結果から，組織の接着機構について の若干の考察を試みる.トマトは組織崩壊に必ずしも酸 やアルカリを必要としなかったことから，すでに成熟状 態にあるために，酵素分解によって組織が単なる物理的 な力（撹拌力）で崩壊しやすくなっていたのではないか と考えられる.力ボチャとサッマイモの組織崩壊には, 酸処理は不要であったが, アルカリ処理が必要であった。 このような組織の接着には，多価金属イオンの役割は小 さく，ペクチンが重要な働きをしているのではないかと 考えられる．酸・アルカリ処理によって崩壊しやすかっ た野菜類，いも類では，多価金属イオンとぺクチンの両 者が重要な㗢きをしているのではないかと考えられる。 酸・アルカリ処理によって崩壊しにくかった野菜類では, 多価金属イオンやペクチンとは異なる成分が重要な働き をしているのではないかと考えられる．酸・アルカリ処 理によって組織が崩壊しなくても軟化した野菜類では, 組織の接着に間接的ではあるが, 多価金属イオンやペク チンが関係しているのではないかと考えられる.

従って，アルカリ単独処理や酸・アルカリ処理による 組織の崩壊の難易は器官の組織の接着機構の違いや接着 カの違いを反映したものと考えられる。

\section{要 約}

野荣類及びい屯類の酸・アルカリ処理による組織の崩 壊の難易について検討した，酸処理は試料に塩酸を加え て上澄み液の $\mathrm{pH}$ を $1.0 \sim 1.5$ として $35^{\circ} \mathrm{C}$ で 1 時間ま たは崩壊しにくい場合は 24 時間放置し，アルカリ処理 は水酸化ナトリウム溶液を加えて上澄み液の $\mathrm{pH}$ を 12.5〜 13.0 として室温で 2 時間擋䢁した。用いた試料
の重量とアルカり処理後の末崩壊物の重量から崩壊度 （\%)を求めた。 その結果, トマト, カボチャ,サッマ イモは酸処理なしで, アルカリ処理のみで, 組織がほぼ 完全に崩壊した。キュウリ，ナス，ピーマン，タマネギ, ニンニク，ユリ根，サトイモ，ジャガイモは酸・アルカ リ処理で組織がほぼ完全に崩壊した。キャベッ，ハクサ イ、レタス，ホウレンソウ，グリーンアスパラガス，フ ロッコリーは酸・アルカリ処理によって組織の 50〜100 \%が崩壊したが，崩壊度のばらつきが大きかった。こ のことは組織の接着機構の不均一性や繊維状組織の存在 に起因するのではないかと推测した。ダイコン、ニンジ ン, ゴボウ，レンコン，ショウガ，クワイは酸・アルカ リ処理による崩壊度が $28 \%$ 以下であり, 組織が崩壊し にくいことが明らかとなった，組織が崩壊しにくいもの の中には酸・アルカリ処理によって軟化するすの（ダイ コン, ニンジン, クワイ）と, しないあの（ゴボウ, レ ンコン,ショウガ) があった，以上の結果から，酸・ア ルカリ処理による組織崩壊の難易は組織の接着機構の違 いを反映したものと考察した.

\section{文献}

1）釗宮正往：日食工誌，37，867 (1990)

2）釘宮正往：日食工誌，39，1001 (1992).

3）佐藤広顕 - 高野克己・光浦暢洋 - 谷村和八郎 - 鴨 居郁三：日食工誌，38, 1071 (1991)

4）渕上倫子：栄食誌, 36, 219 (1983).

5）判上倫子：家政誌，38，465 (1987).

6) 田村咲江：家政誌, 40,995 (1989).

7）新版日本食品事典：杉田浩一・堤 忠一・森 雅 央編（医㐘薬出版，東京）, p. 324 (1982)，

8）市川 収：食品組織学（光生館, 東京), p. 71 (1966).

（平成 5 年 6 月 10 日受理） 